DOI: https://doi.org/10.30525/978-9934-26-108-4-6

Fakhri Fuad Murshudli

Ph.D. in Economics, Doctoral Student of the Chair of «Finance and Financial Institutions» Azerbaijan State University of Economics (UNEC)

Roksolana Zapotichna

Ph.D. in Economics, Lecturer

Lviv State University of Internal Affairs

\title{
TRANSNATIONAL BANKING «UNDER THE DOME» OF THE CORONAVIRUS PANDEMIC: ACTUAL CHALLENGES
}

\begin{abstract}
Summary
The article analyzes changes in the activities of transnational banks (TNBs) taking into account the consequences of the coronavirus pandemic. A review of modern literature on the subject under study was carried out. Given the importance of TNBs for many countries, understanding the scope and direction of current changes is of particular importance to the global economy. Over the past two decades, transnational banking has experienced the following trends: the transformation of credit strategies from aggressive to conservative; South-South banking growth; access to alternative sources of financing; a significant increase in the size of banks; expansion of Chinese banks; strengthening the position of fast-growing markets as home countries of TNBs and the growing importance of developing and emerging markets as host countries of TNBs; geographical differentiation and regionalization of their activities. The results of the study show that the above-mentioned trends are due to a decline in the economies of developed countries and an increase in the economic importance of developing countries. Based on this, we predict a low probability that developed country banks will be active creditors in the near future. Banks from developing countries (especially within their geographical region), whose financial position is much better, can be of great importance in this capacity. It is expected that 2020 will be the year of turning points in the development of transnational banking. A decade after the global economic crisis of 2008-2009, the banking industry faces a new problem that has undoubtedly affected almost every sector of the world economy - the outbreak of coronavirus. Given the lack of research on this topic, the article comprehensively examines the consequences of the crisis pandemic for TNBs.
\end{abstract}




\section{Introduction}

Over the past three decades, the importance of transnational banks (TNBs) for most countries of the world has increased dramatically. TNBs, from both developed and developing countries, not only increased their cross-border capital flows, but also crossed national boundaries and established their physical presence in foreign markets. Given the growing role of TNBs for host countries, questions about their main development directions as well as the challenges they face, including the impact of the 2008-2009 economic crisis and the 2020 coronavirus outbreak, are crucial.

Recent developments in the activities of the TNBs, especially in view of pandemic challenges, have taken place. Given the importance of TNBs in many countries, understanding the scope and direction of these changes for the global economy has become an urgent need. The past two decades have shown trends in international banking, such as the transformation of credit strategies from aggressive to conservative; South-South banking growth; transition to alternative sources of financing; a sharp increase in the size of banks; the increasing expansion of Chinese banks; Strengthening the position of fast-growing markets as home countries of TNBs and the growing importance of emerging markets as host countries of TNBs; geographical expansion and regionalization of their activities.

The results of our study show that the above-mentioned trends are due to the economic downturn in developed countries and the growing economic importance of developing countries. Based on this conclusion, banks from developed countries are projected to become active creditors in the near future. Banks from developing countries have a much better financial position, which increases their relative importance as foreign creditors, especially in their geographical region. It seems that 2020 will be a period of turning points in the development of transnational banking business. A decade after the global economic crisis of 2008-2009, the banking industry faced a new problem that seems to have affected almost all sectors of the world economy - the outbreak of coronavirus. Given the current situation, its implications for the TNBs should be carefully studied.

\section{Part 1. A brief review of post-crisis literature}

The first scientific works on this problem appeared only in the 1970s, and most of them were devoted mainly to general issues of the theory and history of international banking and its role in the economy of developed states. After the economic and social shocks of the 21st century, including the global economic crisis of 2007-2009, the Eurozone debt crisis of the 2010s, the collapse of oil prices in 2014-2015 and the ongoing COVID-19 pandemic, scientists radically changed theoretical, methodological and empirical approaches to studying the problems of international banking. This, in turn, was embodied in the fundamental works published for 2010-2021, in which 
new views prevail on issues related to pressing problems and the potential of international banks in a rapidly changing global environment [1-5].

As the processes of financial globalization deepened and expanded, the range of research priorities for the development of TNBs in the writings of Western researchers expanded markedly. Along with a close study of the theory of the issue, they began to focus on new trends, as well as specific issues of a narrower nature that are of applied importance for international banking. Among them there were the strategy and business models of TNBs [6-8], regulating their activities [9-10], cross-border mergers and acquisitions of TNBs [11; 12], TNB expansion [13; 14] et al.

The surge in international expansion of financial corporations in China, Japan and Korea, as well as foreign banks on the Asian continent has also received scientific and empirical arguments [15-17], trends in international banking services caused by the COVID-19 pandemic [18-20].

It should be noted that the conclusions of Western authors cannot always be considered as universal recommendations, in particular, for the banking systems of the states of the former USSR, which are at the stage of their formation and have certain specificity. In this regard, the topic of the development of the TNB and its certain aspects in the post-crisis years, although not so actively, was worked out by economists in the scientific space of the post-Soviet countries [21-29 et al.].

\section{Part 2. Trends in transnational banking after the economic crisis of 2008-2009}

Based on the databases of «The Banker» and «Global Finance», we can see changes in the TOP-20 of the largest banks by market capitalization for 1990-2019. In 1990, Japanese banks dominated because the economy of this country experienced a relatively high recovery. Among the 20 largest banks there were 9 Japanese, 3 French, 2 Swiss and 1 British bank. The situation changed in the 2000s, when the world rating of banks was headed by US banks - Citigroup and Bank of America. Although most banks on this list were Japanese, their number decreased to 7 . At the same time, the number of American banks doubled. As of 2010, 11 of the 20 largest banks were European, 5 were American, 3 were Chinese, and 1 was Japanese. In 2015, the list of the largest banks was headed by Industrial and Commercial Bank of China (ICBC). However, if in 1990 the TOP-20 included only one bank of China - Bank of China, then in 2015 there were 5 of the 20 largest banks in the world. At the same time, only one Japanese bank - the Mitsubishi UFJ financial group - entered this ranking table, while in 1990 Japanese banks occupied almost half of the list. In 2019, the US and Chinese banks still dominated the TOP-20: 7 were American and 5 were Chinese.

The dominance of Chinese banks was the result of a number of reasons, the most decisive, in our opinion, were the following: 
1) foreign economic policy of the Chinese government, which was called «Go Out Policy» or «Going Global Strategy» [30-34]. The main objective of this policy was to encourage Chinese corporations and banks to invest internationally and enter foreign markets. The goal of the aggressive strategy of expansion of banks abroad was, first of all, to provide access to natural resources and help Chinese business in foreign expansion [60]. The implementation of this policy was also facilitated by China's entry into the World Trade Organization in 2001 [35-37];

2) Chinese banks, due to their relative isolation from the financial systems of developed countries, suffered less from the global financial crisis and, as a result, found themselves in a better position than banks from developed countries - they were able to grow and enter international markets. They pursued an active external expansion strategy at a time when Western banks were forced to consolidate operations abroad, overcoming the consequences of the global financial collapse and the Eurozone debt crisis [27; 38-40];

3) the separation of the political functions of Chinese banks from commercial ones, which led to the creation of China Development Bank and China Export-Import Bank, the key task of which was to achieve the political goals of the Chinese government. This allowed the Big Four banks Industrial and Commercial Bank of China, Agricultural Bank of China, Bank of China and China Construction Bank - to focus on reliable market lending [41-45];

4) strict regulation of foreign banks. In China, the expansion of foreign banks is hampered by local supervisors and regulators, who consistently pursue a policy of limited admission of foreign banks' capital to the national financial system. In the banking sector, the Chinese Government focuses mainly on establishing joint institutions where the Chinese side can access technological and managerial innovations of foreign partners [46-49];

5) Chinese banks operate in markets of a significantly different group of countries (usually those countries for which access to international capital markets is limited) than international financial institutions or western banks, which reduces the level of competition between them. Consequently, Chinese banks have expanded their network into markets undervalued by Western banks, particularly resource-rich African countries [50-52] and the countries of Latin America [53-56]. However, it should be noted that in the last 4 years there has been a downward trend in investment activity of Chinese banks in Latin America. According to research from Boston University and the InterAmerican Dialogue Think Tank, their loans have dropped to 10-year lows as oil deals have weakened and new lenders and partnerships have emerged. [57] Experts suggest that aggregate Chinese funding in the region is unlikely to ever approach its peak level [58].

Another notable trend is the growing importance of developing and emerging countries as hosts of TNBs. According to data collected by S. Claessens and N. van Horen, in 1995, 35\% of TNBs were located in 
developed countries, and 65\% in developing countries, while in $2013-25 \%$ and $75 \%$, respectively [13, p. 28; 59, p. 877]. In other words, in the post-crisis years, developing countries became the main focus of the external expansion of TNBs.

The advantages of developing and emerging countries as host TNBs include higher interest rates, the value of foreign exchange and the demand for foreign loans. They also guarantee a significant market share (about $80 \%$ of the world's population lives in developing countries). From the point of view of S. Prahalad and L. Hart, developing and emerging countries are forming a multimillion-dollar market with a population of about 6 billion people, and this figure will continue to grow. Even the world's poor, living mainly in developing countries, can, under certain circumstances and appropriate policies, become a profitable market for business [60, p. 4, 7].

However, in most developing countries, the presence of TNBs is still quite limited. This is primarily due to the unpredictability of policy and legal changes in these countries (some of them have strict currency laws that may vary depending on the state of foreign exchange reserves and the balance of international payments), as well as difficulties in repatriating profits (host countries may require income to be spent domestically rather than transferred to their homeland).

One of the important trends in the development of TNBs after the economic crisis of 2008-2009 was the sharp expansion of the geography of their activities. While in 1995 TNBs were absent in 19 countries, in $2009-$ in 11 (Cuba, Ethiopia, Haiti, Iceland, Iran, Libya, Oman, Qatar, Saudi Arabia, Sri Lanka and Yemen) [61, p. 10], and in 2019 - in only two - Ethiopia and Iceland (based on the analysis of data from the central banks of these countries).

After the Latin American debt crisis of the 1980s and the Asian financial crisis of 1997-1998, the banking system and the credit strategy of the TNB underwent sharp changes. The transition to a decentralized banking system slowed down in the mid-2000s. Direct cross-border credit to developing countries has recovered from the strengthening of the dollar. In addition, the introduction of the euro and significant investments of European banks in US securities had a similar effect [62].

Both direct and indirect loans peaked in the first quarter of 2008 and subsequently began to decline. During 2008-2009, trends in the global economic crisis varied significantly depending on the group of host countries analyzed: while in developed countries direct and indirect loans decreased annually - by $0.9 \%$ and $3 \%$, respectively, in developing countries direct loans decreased (on average by $0.3 \%$ annually), and indirect loans increased by $0.8 \%$ [63].

The reduction in loans can be explained by various factors, three of which are decisive, according to E. Cerutti and S. Claessens. Firstly, the deterioration of the TNB balance sheet, when many of them faced a shortage 
of capital and liquidity, especially during 2008-2009. Secondly, the decline in demand for loans is due to the deterioration of economic conditions, as well as an increase in defaults and other risks from host countries. Thirdly, there are growing regulatory constraints and uncertainty about the future of the global banking system, as well as the rules governing it, including the possibility of free movement of resources within transnational banking groups and across borders. All these factors forced banks not only to adjust their credit strategies in foreign markets, but also required a special approach to it. This was manifested in particular in the reduction of direct cross-border loans to a greater extent than indirect ones [64, p. 16].

After the global economic crisis, the previous trend towards a decentralized banking system intensified further. One of the main post-crisis trends was a slowdown in growth and a reduction in cross-border lending. Due to financial constraints, many TNBs, especially those from Europe, were forced to reduce their cross-border loans and transfer their financial resources to the domestic market of the country of origin. This trend has raised fears among economists that the global financial system is undergoing a period of «deglobalization» and fragmentation. However, the sharp increase in direct cross-border loans in Asia, in our opinion, is not a reduction in transnational lending, but a change in global credit flows and the growing importance of Asian banks.

\section{Part 3. Transnational banking after coronavirus outbreak: trends and shifts}

The global economic crisis of 2008-2009 took more than a year to spread from the suburbs of California and southern Spain to the financial centers of the world. At the same time, the 2020 coronavirus outbreak took only 3 months to reach first China and then Europe and North America. The spread of coronavirus infection COVID-19 westward caused an economic crisis, the «buzz» of which should exceed everything previously observed by transnational banking [65].

The outbreak of coronavirus, which has quickly evolved from a public health problem to a major problem for the global economy, could accelerate the reversal of previous trends in international banking.

Most economists and scholars emphasize that banks entered this crisis in a better position than during the economic crisis of 2008-2009, when a sharp decline in bank lending aggravated the impact of the global crisis on the economy. According to J. Marus, before the outbreak of coronavirus, the banking industry was experiencing an unprecedented period of growth and prosperity. Despite growing consumer expectations and increased competition from non-traditional (alternative) financial institutions, most banks and credit unions were stronger than in any period after the crisis of 2008-2009 [66].

Higher levels of capital buffers, increased supervision and regulation, support for liquidity by central banks put TNBs in a better position than at the beginning of the global economic crisis of 2008-2009. This time, banks are 
even considered as part of the solution, and they are given the opportunity to improve their image. But it also puts them in some painful dilemmas. However, the sustainability of banks can be tested in some countries in the face of large market and credit losses, and this can lead to their reducing lending to the economy, which will undoubtedly significantly slow down their activity.

As stated in the IMF review of global financial stability in markets during the coronavirus pandemic, «this crisis poses a very serious threat to the stability of the global financial system. After the outbreak of COVID-19, financial conditions tightened at an unprecedented rate... Market volatility increased sharply, and borrowing costs increased amid expectations of widespread defaults» [67].

Weakening of TNBs from China. Given the fact that the coronavirus outbreak was first detected in China, Chinese TNBs could not remain outside observers as the crisis developed. According to B. Caplen, «Chinese banks will suffer from the growth of distressed loans as a result of the outbreak of coronavirus, and TNBs need to reconsider the issue of financing supply chains» [68].

In difficult times, China always turns to its banks. A similar scenario was used by the government to pump demand into the economy after the financial crisis 12 years ago. Thus, it is likely that they will again be called upon to support the economy, as it weakens as the coronavirus spreads. At the same time, less favorable conditions are being formed to assist Chinese banks than during the global crisis of 2008-2009, and as a result of coronavirus they receive a direct blow to their balance sheets, which was not previously observed. Even in 2008-2009, this was not noted, since subprime bad assets that caused the financial crisis belonged mainly to Western banks. In addition, they were characterized by high sustainability and large free capital, which allowed them to issue new loans worth billions of dollars and help maintain China's high economic growth, while in general the world economy and, in particular, the economies of its main trading partners were declining [68].

Moreover, China's banking regulator has already been pressured to address the problem of shadow banking [69-72] and the growing amount of nonperforming loans [73-76]. However, coronavirus and its direct impact on China's economy means curtailing all planned reforms to focus on the country's banking system with hundreds of billions of dollars of new inoperative assets.

In the context of economic recovery, large banks in the country also risk increasing the volume of bad loans [77; 78]. The gains of China's four major state-owned commercial banks, which are TOP-20 banks and major global lenders, are expected to stall and bad debts are likely to accumulate, as banks carry out both their own responsibilities and nationwide measures to help combat the economic collapse caused by the pandemic. This, in our opinion, will affect the decrease in lending carried out by Chinese banks in certain 
regions of the world. For example, it has already been noted that there is such a trend in Latin America, even before the global spread of COVID-19 created a gloomy economic outlook for 2020 [66]. It can be assumed that such a trend will not be long-term for this region, considering that these TNB envisage the resumption of financing and the creation of projects that contribute to the formation and development of the New Silk Road in Latin America [79].

After the outbreak of coronavirus in January 2020, the Chinese government ordered the country's banks to help rebuild the country's economy, continuing to lend to troubled companies while lowering interest rates. Such «national duty» is common practice for state-owned companies in China and often involves making non-commercial decisions to help the economy at the expense of profits. People's Bank of China has already cut its benchmark interest rate on loans to help companies lend less, and analysts expect it to cut it repeatedly, further reducing net interest margins - a key indicator of bank profitability. ICBC - the world's largest commercial bank in terms of assets received a net profit of 44 billion USDin 2019, which is $4.9 \%$ more than in the previous year. Bank of China reported a $4.1 \%$ increase in profit, but at the same time, in its annual report, admitted the likelihood of the impact of coronavirus on the quality of the group's assets. The Agricultural Bank of China, the country's third largest commercial bank, warned that the pandemic could cause stress among its manufacturing customers [80].

The changing role of developing and emerging countries as hosts of TNBs. In economic publications, the outbreak of coronavirus is already called the «largest crisis in emerging markets.» Many developing and transitive countries face enormous challenges when their populations are in danger, their public finances are in trouble, and financial markets are in a state of major shocks.

Global shock has an uneven chronology. In the West, it was the virus that caused the financial crisis. In large developing countries of the world economy (such as Argentina, Brazil, sub-Saharan Africa, India, Thailand and Malaysia), the virus has not yet reached full strength: for them, a wave of financial shock is ahead of the pandemic. The merging of the two crises threatens to create a huge whirlpool for developing and emerging countries, whose impact on the world economy will be enormous.

Historically, significant capital outflows have exacerbated domestic shocks in emerging and developing economies. These events increased the risk of the inability of borrowers to service their own debts, which, without condition, will put pressure on banks and lead to a freeze in credit markets. A long period of dislocation in financial markets can provoke stress among financial institutions, which, in turn, will lead to a credit crisis for non-financial borrowers, and this, of course, will further aggravate the economic recession [65].

Transition from globalization to regionalization. Experts argue that after the outbreak of coronavirus, the world will become completely different, as the pandemic begins to destroy the foundations of globalization. At the same 
time, they note that the outbreak of coronavirus does not threaten the future of globalization and is unlikely to put an end to it, but is likely to change for the better.

In 2008, due to the onset of the economic crisis, the world successfully rallied, while in 2020, it faced with the threat of an outbreak of coronavirus, each country was committed to the principle of «for itself». Governments and banks have not coordinated their economic response to this threat [81]. The impact of the virus has been highly regionalized, but the effects of public policy are becoming increasingly nationalized.

Globalization could be the biggest victim of the pandemic. A closely interconnected global economy not only contributes to the spread of coronavirus, but also exacerbates the negative economic consequences. Open economies, with a developed banking sector, are particularly vulnerable to the economic shocks associated with the coronavirus outbreak. Economic losses, in turn, will strengthen the forces of protectionism and isolationism. As a result, banking can become more localized and regionalized [82].

European banks are under intense pressure as the coronavirus stops all major economies at a time when these institutions were still struggling with the legacy of the 2008-2009 economic crisis. The region's creditors have undergone large-scale transformations since 2008, strengthening their capital positions in compliance with stricter rules. However, they struggled to return their markets to pre-crisis levels. From March 2008 until the beginning of this year, the European banking index continued to decline by more than $50 \%$, while sales in world markets under the influence of the virus indicate that now the same index has decreased by $70 \%$ compared to March 2008. «European banks remain vulnerable and fragile to financial and debt crises, and the coronavirus crisis is taking a new toll on the financial sector, adding to investor uncertainty» [83].

The scientific literature emphasizes that lending at the regional level may be more attractive than lending at the global level. Banks can benefit from regional specialization because they acquire specific knowledge. Consequently, when TNBs are already active in a particular region, they are likely to seek to expand their presence in the same region. Moreover, TNBs tend to concentrate their activities in markets within their geographical region or in the markets of countries that have close historical ties (colonial dependence, etc.) with their home country [84].

\section{Conclusions}

According to the results of the study, the following conclusions can be drawn:

- before the 2020 coronavirus outbreak, the banking sector was much stronger than before the global economic crisis of 2008-2009. This time, banks are even considered as a potential means to overcome the crisis. For 
TNB, one of the main problems of the 2020 crisis is the level of problem loans;

- after the crisis of 2008-2009, the financial position of TNBs from China and other fast-growing markets strengthened, and their importance for the global economy increased sharply. On the contrary, due to the outbreak of coronavirus and its consequences for the Chinese economy, this country is likely to lose its position as the home and host country of large TNBs;

- during and after the coronavirus outbreak period, there will be a steady trend in international banking towards a regional model, as opposed to the global model they used previously. In other words, TNBs are likely to focus on local and regional areas rather than on the global market.

\section{References:}

1. Danielson A. G. (2016). International Banking: America's Rising Role: How Four American Banks Assumed Worldwide Leadership. Massachusetts: SDP Publishing Solutions. 86 p.

2. Demirguc-Kun A., Evanoff D. D., Kaufman G. G. (Eds.). (2017). The Future of Large, Internationally Active Banks. Singapore: World Scientific Publishing Co. xiv, 479 p.

3. Eray C. (2020) Multinational Banks and Foreign Expansion Decisions. Cham: Palgrave Macmillan. xix, 98 p. DOI:10.1007/978-3-030-36879-1

4. Finel-Honigman I., Sotelino F.B. (2015) International Banking for a New Century. London: Routledge. xi, 256 p.

5. Weston R. (2012) Domestic and Multinational Banking: The Effects of Monetary Policy. London: Routledge. DOI:10.4324/9780203109199

6. Argimón I. (2019) Spanish banks' internationalization strategy: characte- ristics and comparison. Economic Bulletin, 1. Banco de España. Analytical articles. 10 January. 10 p.

7. Everett M., McQuade P., O’Grady M. (2020) Bank business models as a driver of cross-border activities. Journal of International Money and Finance, 17 February, 102164.

8. McCauley R., McGuire P., von Peter G. (2010) The architecture of global banking: from international to multinational? BIS Quarterly Review. Basel. March, pp. 25-37.

9. Calzolari G., Colliard J.-E., Loranth G. (2016) Multinational Banks and Supranational Supervision. CEPR Discussion Paper 11326, June.

10. Navaretti G. B., Calzolari G., Pozzolo A. F., Levi M. (2011) Multinational Banking in Europe: Financial Stability and Regulatory Implications: Lessons from the Financial Crisis. Centro Studi Luca d’Agliano Development Studies Working Paper. No. 292. 06 April.

11. Latorre G. R. (2019). Caution shrouds optimism: Global banking M\&A trends 2019. KPMG International. May.

12. Rao-Nicholson R., Salaber J. (2016). Impact of the financial crisis on cross-border mergers and acquisitions and concentration in the global banking industry. Thunderbird International Business Review, 58(2), March/April, pp. 161-173. DOI: 10.1002/tie.21731

13. Claessens S., Van Horen N. (2014). Foreign Banks: Trends and Impact. Journal of Money, Credit and Banking, 46(1), February, pp. 295-326. DOI: 10.1111/ jmcb.12092

14. Iwanicz-Drozdowska M., Bongini P., Smaga P., Witkowski B. (2018). ForeignOwned Banks: The Role of Ownership in Post-Communist European Countries. Cham: Palgrave Macmillan. xiv, 220 p. DOI: 10.1007/978-3-030-01111-6

15. Li Y., Hernandez E., Gwon S. (2018). When Do Ethnic Communities Affect Foreign Location Choice? Dual Entry Strategies of Korean Banks in China. Academy of Management Journal. 21 March. 45 p. 
16. Nishimura T., Sugawara A. (2020) The Development of International Banking in Asia. Springer Japan. xviii, 408 p. DOI: 10.1007/978-4-431-55615-2

17. Phillips M., Yung R., Leung J., Yung W. (2014) Foreign banks in China 2013. Pricewaterhouse Coopers. January.

18. Kearney A. T. (2020) COVID-19 crisis response for financial institutions: Key aspects and business implications. Available at: https://www.kearney.com/covid19/article/?/a/six-steps-to-weathering-the-covid-19-outbreak-for-financialinstitutions

19. OECD. (2020) Global Financial Markets Policy Responses to COVID-19. Available at: https://www.oecd.org/coronavirus/policyresponses/global-fnancial-markets-policyresponses-to-covid-19-2d98c7e0

20. McKinsey \& Company (2020) Leadership in the time of coronavirus: COVID-19 response and implications for banks. March 17. Available at: https:// www.mckinsey.com/ industries/fnancial-services/our-insights/leadership-in-the-timeof-coronavirus-covid-19response-and-implications-for-banks

21. Abalkina A. A. (2016). Jekspansija rossijskih bankov za rubezh: jempiricheskij analiz [Expansion of Russian banks abroad: empirical analysis]. Moscow: IE RAS. (in Russian)

22. Vladychin W. V. (2015) Derzhavne rehuliuvannia inozemnoho bankivnytstva v Ukraini [State regulation of foreign banking in Ukraine]. Lviv: LNU named after I. Franco. (in Ukrainian)

23. Ivanova N. I., Klimanova E. N. (2017) Mezhdunarodnaja dejatel'nost' rossijskih bankov [International activities of Russian banks]. Beau-Bassin Rose-Hill: LAP Lambert Academic Publishing. (in Russian)

24. Koldovsky A. V. (2014) Jekspansija inostrannogo kapitala v bankovskij sektor Ukrainy [Expansion of foreign capital into the banking sector of Ukraine]. Saarbrücken: LAP Lambert Academic Publishing. (in Russian)

25. Loginov B. B. (2016) Mezhdunarodnyj bankovskij biznes [International banking business]. Moscow: Urright. (in Russian)

26. Momot A. M. (2018) Vymiry ekspansii transnatsional'noho bankivs'koho kapitalu v Ukraini ta sviti [Measurements of the expansion of transnational banking capital in Ukraine and the world]. Kharkov: FLP Panov A. M. (in Ukrainian)

27. Murshudli F. F. (2013) Bankovskoe obsluzhivanie vneshneekonomicheskoy deyatelnosti Azerbaydzhana $\mathrm{v}$ usloviyah finansovoy globalizatsii [Banking services of foreign economic activities of Azerbaijan in the conditions of financial globalization]. Baku: East-West, xvi. (in Russian)

28. Yarygina I. Z. (ed.) (2020) Mezhdunarodnyj bankovskij biznes [International banking business]. Moscow: MGIMO-University. (in Russian)

29. Volkova E. K. (2021) Transnational and Regional Banks. Financial Markets Evolution. Panova G. (ed.) Cham: Palgrave Macmillan. xxvi, 347 p. doi: 10.1007/978-3030-71337-9_12

30. Abeliansky A. L., Martínez-Zarzoso I. (2019) The relationship between the Chinese «going out» strategy and international trade. Economics: The Open-Access, OpenAssessment E-Journal, 13(21), March 11, pp. 1-18.

31. China Policy. (2017). China Going Global between ambition and capacity. Beijing. April. 12 p. Available at: https://policycn.com/wp-content/uploads/2017/05/2017-Chinasgoing-global-strategy.pdf

32. Li R., Cheong K. C. (2019) «Going Out», Going Global, and the Belt and Road / China's State Enterprises. Singapore: Palgrave Macmillan, pp. 151-194.

33. Nash P. (2012). China's «Going Out» Strategy. Diplomatic courier. May 10. Available at: https://www.diplomaticourier.com/posts/china-s-going-out-strategy 
34. Wang H. (2016). A Deeper Look at China's «Going Out» policy. Centre for International Governance Innovation commentary. March 8. Available at: https:// www.cigionline.org/sites/default/files/hongying_wang_mar2016_web.pdf

35. Zhang C., Zhang T., Tan T. (2020). Internationalization of Chinese Banks: How to Strengthen and Enhance Overseas Operations and Management. Proceedings of the 5th International Conference on Financial Innovation and Economic Development (ICFIED 2020). 11 March, pp. 144-150. doi: 10.2991/aebmr.k.200306.026

36. Borst N., Creehan S. (2015). Asian Banks Go Global. Federal Reserve Bank of San Francisco. July 17. Available at: http://www.frbsf.org/banking/asia-program/pacificexchange-blog/asian-banks-go-global

37. Graham B. (2012). China's Accession to the WTO: Economic Benefits. The Park Place Economist, 20(1), pp. 13-17. Available at: http://digitalcommons.iwu.edu/ parkplace/vol20/iss1/8

38. Mavroidis P. C., Sapir A. (2019). China and the World Trade Organization: Towards a Better Fit. Bruegel. Working paper, 06, 11 June. 46 p. Available at: https://www.bruegel.org/wp-content/uploads/2019/06/WP-2019-06-110619.pdf

39. Calkins J. (2013). Banking Abroad: The Globalization of Chinese Banks. CKGSB Magazine, 9, March. Available at: https://knowledge.ckgsb.edu.cn/2013/03/28/ china/banking-abroad-the-globalization-of-chinese-banks

40. Pan F., He Z., Sigler T., Martinus K., Derudder B. (2018). How Chinese Financial Centers Integrate into Global Financial Center Networks: An Empirical Study Based on Overseas Expansion of Chinese Financial Service Firms. Chinese Geographical Science, 28(2), pp. 217-230. doi: 10.1007/s11769-017-0913-7

41. Shenglin B., Yu J., Gu Y., Lv J., Zhang L., Gong H., Gu H., Shuai Q. (2018). Pursuit of Presence or Prominence? The Prospect of Chinese Banks' Global Expansion and Their Benchmarks. Springer Singapore, xxvi, 167 p.

42. Berger A. N., Hasan I., Zhou M. (2009) Bank ownership and efficiency in China: What will happen in the world's largest nation? Journal of Banking \& Finance, no. 33(1), pp. 113-130.

43. Fungáčová Z., Pessarossi P., Weill L. (2013). Is bank competition detrimental to efficiency? Evidence from China. China Economic Review, no. 27, pp. 121-134.

44. Tan Y. (2015). Performance, risk and competition in the Chinese banking industry. Kidlington, Oxford: Chandos Publishing. 264 p.

45. Xu J., Gan C., Hu B. (2013) An empirical analysis of China's Big four state-owned banks' performance: A data envelopment analysis. Journal of Banking Regulation, no. 16(1), pp. 1-21.

46. He W. P. (2014) Banking Regulation in China: The Role of Public and Private Sectors. Palgrave Macmillan US. xi, 244 p.

47. Luo D. (2016) The Development of the Chinese Financial System and Reform of Chinese Commercial Banks. Palgrave Macmillan UK. xiii, 247 p.

48. Pricewaterhouse Coopers. (2014) Foreign banks in China 2013. January. 74 p.

49. Wang Y., Chenavaz R. (2016) The Entry of International Banks in China. The Journal of Applied Business Research, no. 32(5), pp. 1495-1506.

50. Abdulai D. N. (2017) Chinese Investment in Africa. Routledge. xviii, 183 p.

51. Ayodele T., Sotola O. (2014) China in Africa: An Evaluation of Chinese Investment. IPPA Working Paper Series. 20 p.

52. Bräutigham D. (2011) China in Africa: What can Western Donors Learn?. Oslo: Norwegian Investment Fund for Developing Countries (Norfund). August. 18 p.

53. Avendano R., Melguizo A., Miner S. (2017) Chinese FDI in Latin America: new trends with global implications. The Atlantic Council of the United States and The OECD Development Centre. June. 21 p. 
54. Kaplan S. B. (2016) Banking unconditionally: the political economy of Chinese finance in Latin America. Review of International Political Economy, no. 23(4), pp. 643-676.

55. Roby V. (2020) China's Growing Influence in Latin America. American Journal of Economics and Sociology, no. 79(1), January, pp. 233-244. doi:10.1111/ajes.12316

56. Vadell J., Neves P. (2014) A new donor in Latin America: Chinese banks and the end of the Washington Consensus. Buenos Aires: FLACSO/ISA. 23 p.

57. Ray R., Barbosa P. H. B. (2020) China-Latin American Economic Bulletin. Boston University - Global Development Policy Center. March 18. 20 p. Available at: https://www.bu.edu//gdp/files/2020/03/GCI-Bulletin_2020.pdf

58. Myers M., Gallagher K. (2020) Scaling Back: Chinese Development Finance in LAC, 2019. China-Latin America Report. March. 8 p.

59. Claessens S., Van Horen N. (2015) The Impact of the Global Financial Crisis on Banking Globalization. IMF Economic Review, no. 63(4), pp. 869-918.

60. Prahalad C. K., Hart S. L. (2008) The Fortune at the Bottom of the Pyramid. Estratégia\&Negócios, 1(2), Jule. 23 p. Available at: http://portaldeperiodicos.unisul.br/ index.php/EeN/ article/viewFile/39/39

61. Claessens S., Van Horen N. (2012) Foreign Banks: Trends, Impact and Financial Stability. IMF Working Paper, No. 12/10. January. 39 p.

62. McCauley R., McGuire P. (2009) Dollar Appreciation in 2008: Safe Haven, Carry Trades, Dollar Shortage and Overhedging. BIS Quarterly Review, December, pp. 85-93.

63. Zapotcihna R. (2016) Analysis of the activities of multinational banks in the countries of the world during 1980-2015. Visnyk ONU, no. 21(9), pp. 12-16.

64. Cerutti E., Claessens S. (2014) The Great Cross-Border Bank Deleveraging: Supply Constraints and Intra-Group Frictions. IMF Working Paper, No. 14/180. 37 p.

65. Tooze A. (2020) The Coronavirus Is the Biggest Emerging Markets Crisis Ever. Available at: https://foreignpolicy.com/2020/03/28/coronavirus-biggest-emerging-marketscrisis-ever

66. Marous J. (2020) Reimagining Banking During and After COVID-19. The Financial Brand Newsletter. April 1. Available at: https://thefinancialbrand.com/ 94256/reimagining-digital-banking-transformed-covid-19-coronavirus-trends

67. IMF. (2020) Global Financial Stability Report: Markets in the Time of COVID-19. April. xiii, $102 \mathrm{p}$.

68. Caplen B. (2020) How will the coronavirus impact China's banks? The Bankers, February 11. Available at: https://www.thebanker.com/Editor-s-Blog/How-will-thecoronavirus- impact-China-s-banks

69. Bryane M. (2014) Playing the Shadowy World of Emerging Market Shadow Banking. IEMS Emerging Market Brief, 14-02, April. 35 p.

70. Jiang W. (2015) The Future of Shadow Banking in China. Columbia Business School Research Paper, No. 16-33. September 15. 12 p. DOI:10.2139/ssrn.2769603

71. Li J., Hsu S. (2019) Shadow Banking in China: Instruments, Issues, Trends. In Shadow Banking: Scope, Origins and Theories. Ed. by A. Nesvetailova. Routledge. January 23. xii, 250 p.

72. Xi C., Xia L. (2017) Shadow Banking in China: Then and Now. IMI Working Paper, No. 1711. July. 13 p.

73. Kossof P. (2014) China's Non-Performing Loans: History, Current Infrastructure, and the Future of Bad Debt in China. International Journal of Law and Legal Jurisprudence Studies, 1(6), October 4, pp. 1-35. DOI: 10.2139/ssrn.2505450

74. Rehman R., Naseem M.A., Ahmad M.I., Ali R. (2019) Chinese Banking Reforms: An Analysis and Evaluation of Non-Performing Loans. Agathos: An International Review of the Humanities \& Social Sciences, no. 10(2), pp. 331-348. 
75. Zhang D., Cai J., Dickinson D. G., Kutan A. M. (2016) Non-performing loans, moral hazard and regulation of the Chinese commercial banking system. Journal of Banking \& Finance, no. 63, pp. 48-60. DOI:10.1016/j.jbankfin.2015.11.010

76. Zhu N., Wang B., Wu Y. (2015). Productivity, efficiency, and non-performing loans in the Chinese banking industry. The Social Science Journal, no. 52(4), pp. 468-480.

77. Mann I., Ridgers C. (2018) New opportunities in China's non-performing loan market. Australian Restructuring Insolvency\&Turnaround Association Journal, 30(3), p. 32-33. Available at: https://search.informit.com.au/documentSummary;dn=883270127093514; res=IELAPA

78. Peresa I., Vidon E. (2019) Draining bad loans in China: bad banks are not enough. EcoNotepad - post $n^{\circ}$ 133. September 19. 3 p. Available at: https://blocnotesdeleco.banquefrance.fr/sites/default/files/billet_133_ve_recontribue.pdf

79. Ugarteche O., de Leyn C. (2020) China's Financing of Latin America. OBELA. Num. 4, 3rd March. 3 p. Available at: http://www.obela.org/en-analisis/chinas-financingof-latin-america

80. Weinland D. (2020) China's big four banks face coronavirus profit hit. Financial Times, April 1. Available at: https://www.ft.com/content/606e5e25-f537-4c57-8376c8343a69c73f

81. Hutton W. (2020) Coronavirus won't end globalization, but change it hugely for the better. The Guardian. March 8. Available at: https://www.theguardian.com/ commentisfree/2020/mar/08/the-coronavirus-outbreak-shows-us-that-no-one-can-take-onthis-enemy-alone

82. Huang Y. (2020) Coronavirus and the World Economy. Think Global Health. February 24. Available at: https://www.thinkglobalhealth.org/article/coronavirus-andworld-economy

83. Amaro S. (2020) 12 years after Lehman, European banks face a new credit crisis. CNBC. March 20. Available at: https://www.cnbc.com/2020/03/20/coronavirus-hitseuropean-banks-as-they-still-face-post-crisis-issues.html

84. Ehlers T., Wooldridge P. D. (2015) Channels and Determinants of Foreign Bank Lending. BIS Papers, no. 82, pp. 29-68. 